This PDF is a selection from a published volume from the National Bureau of Economic Research

Volume Title: International Trade in Services and Intangibles in the Era of Globalization

Volume Author/Editor: Marshall Reinsdorf and Matthew J. Slaughter, editors

Volume Publisher: University of Chicago Press

Volume ISBN: 978-0-226-70959-8; 0-226-70959-0

Volume URL: http://www.nber.org/books/rein09-1

Conference Date: April 28-29, 2006

Publication Date: May 2009

Chapter Title: International Trade in Motion Picture Services

Chapter Author: Gordon H. Hanson, Chong Xiang

Chapter URL: http://www.nber.org/chapters/c11610

Chapter pages in book: (203 - 222) 


\title{
International Trade in Motion Picture Services
}

\author{
Gordon H. Hanson and Chong Xiang
}

\subsection{Introduction}

In the last dozen years, empirical research in international trade has blossomed. There are now extensive bodies of work on testing the Heckscher-Ohlin trade model (Davis and Weinstein 2002), examining the impact of globalization on wages and productivity (Feenstra and Hanson 2002; Tybout 2002), and estimating how trade flows respond to trade costs (Anderson and van Wincoop 2004), among other topics. These strands of literature, however, are almost entirely about international trade in manufactures. Due in part to a paucity of data on service trade flows, relatively few papers address international trade in services (e.g., Freund and Weinhold 2002, Amiti and Wei 2005, and Marvasti and Canterberry 2005). Indicatively, Feenstra's (2004) recent graduate text on international trade includes no references to research on trade involving service industries.

Yet, for the United States and other advanced countries it is services in which their export strength increasingly lies. The 2004 Economic Report of the President touts information services (Internet publishing and service provision, motion pictures, printed media, radio and TV programming, software, sound recordings, telecommunications) and professional services (accounting, advertising, architecture, consulting, engineering, law, R\&D services) as sectors with the highest recent growth in U.S. net exports. In 2002, U.S. exports and foreign sales of information services were $\$ 90$ billion, relative to total service exports of \$295 billion and manufacturing exports of $\$ 627$ billion (Siwek 2004). In 2003, information services were 5

Gordon H. Hanson is a professor of economics at the University of California, San Diego, and a research associate of the National Bureau of Economic Research. Chong Xiang is an assistant professor of economics at Purdue University. 
percent of U.S. GDP (relative to 14 percent for manufacturing), and exports of U.S. motion pictures accounted for 73 percent of box office revenues in Europe (Siwek 2005).

Why are services such an important part of the U.S. tradables production? One possibility is that the United States has a comparative advantage in tradable services, due to the country's abundant supply of workers (either native or foreign born) with advanced degrees (computer scientists, engineers, lawyers, MBAs) or specialized skills (actors, musicians, recording technicians, screenwriters), which information and professional services use intensively. Reductions in trade costs - associated with improvements in information technology or falling cultural barriers to trade - may have accentuated the U.S. comparative advantage in services. A second possibility is that scale economies may give service providers an incentive to locate in the large U.S. market (Rauch and Trindade 2006). For many information services, average costs decline sharply in output. Where these services are provided in a specific language or cultural context, large markets may be the optimal site for global production (Krugman 1980; Helpman and Krugman 1985). So far, empirical literature has found evidence that large markets affect trade only in manufacturing (Feenstra, Markusen, and Rose 1998; Davis and Weinstein 1999 and 2003; Head and Ries 2001; Hanson and Xiang 2004).

In this paper, we present data on U.S. trade in motion pictures and examine the determinants of U.S. motion picture exports using a modified version of the gravity model. Our focus on motion pictures is warranted by the importance of information services to the U.S. economy and their role in current debates about trade policy. Information services embody large amounts of intellectual property, whose accumulation appears to be important for economic growth but whose ownership rights are often difficult to enforce across national borders (McCalman 2004). Beyond the threat of piracy, many governments aggressively restrict imports of motion pictures and sound recordings, ostensibly to preserve domestic production of cultural goods (Janeba 2004).

In section 6.2, we derive a gravity model of trade in which a country's imports of U.S. motion picture services relative to its expenditure on domestically produced motion picture services depends on the country's size relative to the United States, proximity to the United States in terms of geography and culture, and other trade costs. We measure cultural trade costs using indicators of linguistic distance between countries in Dyen, Kruskal, and Black (1992), Melitz (2002), and Chiswick and Miller (2004), and policy trade barriers using data on the motion picture industry collected in Marvasti and Canterberry (2005).

Given limited public data, empirical research on trade in services requires one to assemble information from private sources. In section 6.3, we describe available data on U.S. exports of motion pictures. The publicly available data on motion picture trade flows appear to be of dubious 
quality. ${ }^{1}$ The U.N. Comtrade database reports trade in motion pictures in terms of the value of cinematographic film exposed or developed, which is a commodity rather than a service. Importers appear to have considerable discretion in reporting the value of physical film prints, as Comtrade trade flows are up to two orders of magnitude smaller than foreign box office revenues for U.S. films compiled by Screendigest.com, a private industry source. What makes motion pictures an attractive case to study is that bilateral trade in the industry is easily measured at the point of consumption (movie cinemas, video rental stores, pay TV operators), which facilitates their collection by private consultancies. We use data from Screendigest.com, as reported in Hancock and Jones (2003), to estimate a gravity model of trade for the motion picture industry, the results for which we report in section 6.4. The estimates indicate how market size and trade costs affect trade in motion pictures.

Though information services are among the most dynamic sectors in the U.S. economy, they have been the subject of little research by international economists. Key to new research efforts will be the collection of data on service trade flows. Since service trade rarely passes through ports, airports, or land borders, it is difficult to detect using standard government methods for measuring imports and exports. A further problem is that the channels through which firms export or import services change continually over time. In the early 1990s, most foreign revenue on U.S. motion pictures was generated at the box office. By the late 1990s, videos, DVDs, and pay TV had become important sources of foreign film distribution. Going forward, the Internet may become the dominant mode for film distribution. Given rapid change in the distribution of services, and the slow speed with which government data collection strategies tend to change, private industry sources are likely to be the most useful data source for research on trade in services in the near term.

\subsection{Trade Theory and Trade in Information Services}

We base our model of information services on Hanson and Xiang (2004), which extends the monopolistic-competition model of trade (e.g., Helpman and Krugman 1985) to a continuum of industries. The setup has a large country and a small country, each with one production factor, labor (though the extension to a many-factor setting is straightforward). There are many industries, some of which are information services (movies, music) and others of which are manufactures (cars, clothes). Production of each good or service is subject to increasing returns to scale. Consumers have identical Cobb-Douglas preferences. Each industry consists of many

1. The difficulty of measuring economic activity in services has been studied in much other work. On measurement issues related to services, see Hooper and Richardson (1991), Griliches (1992), Baldwin, Lipsey, and Richardson (1998), and Berndt and Hulten (2007). 
Dixit-Stiglitz-type varieties (action movies, comedies), the number of which is endogenous. For industry $m$, let $n_{m}$ denote the number of varieties and $\sigma_{m}$ denote the elasticity of substitution between varieties, where $\sigma_{m}>$ 1. Each manufacturing industry is subject to an iceberg transport cost, $\tau_{m}>1$.

Information services are subject to a cultural discount and perhaps a policy trade barrier (in the form of a tariff or quantity restriction). For a consumer, one unit of a domestic service brings as much satisfaction as $1 /$ $\delta$ units of a foreign service, where $0<\delta<1$. We expect $\delta$ to be higher the more similar are two countries' culture and language. Domestic and foreign varieties of an information service are symmetric in consumption. For each information service $i, \sigma_{i}>1$ is the elasticity of substitution between varieties.

Given increasing returns to scale and constant elasticity of substitution (CES) preferences, in equilibrium each service firm and each manufacturing firm is monopolistically competitive and sets a price that is a constant markup over marginal cost. Prices for a given variety of a good or service produced in a given country vary across destination markets according to trade costs.

Based on this framework, let $S_{i u k}$ and $S_{i k k}$ be total sales of information service $i$ by country $u$ (the United States) to country $k$ and by country $k$ to itself. Exploiting the CES structure of preferences, we obtain the following expression for relative sales:

(1) $\frac{S_{i u k}}{S_{i k k}}=\frac{E_{i k} n_{i u}\left(\delta_{i u k}\right)^{1-\sigma_{i}}\left(p_{i u k} / P_{i k}\right)^{1-\sigma_{i}}}{E_{i k} n_{i k}\left(p_{i k k} / P_{i k}\right)^{1-\sigma_{i}}}=\frac{n_{i u}}{n_{i k}}\left(\frac{w_{i u}}{w_{i k}}\right)^{1-\sigma_{i}}\left(\delta_{i u k}\right)^{1-\sigma_{i}}\left(t_{i u k}\right)^{1-\sigma_{i}}$,

where $E_{i k}$ is expenditure by country $k$ on service $i, P_{i k}$ the CES price index in country $k$ for service $i$, and $p_{i u k}$ is the delivered price (including customs, insurance, and freight charges) in country $k$ of service $i$ produced by country $u, w_{i u}$ is marginal production cost in service $i$ and country $u$, and $t_{i u k}$ is the ad valorem trade cost on exports from country $u$ to country $k$. The second equality follows from solving for price in terms of marginal cost. Expressing sales in relative terms removes the CES price index and domestic expenditure from the expression, as shown in the second equality. In the estimation, we will associate the cultural discount $\left(\delta_{i u k}\right)$ with linguistic distance and ad valorem trade costs $\left(t_{i u k}\right)$ with geographic distance, import tariffs, and other policy trade barriers.

One can implement equation (1) empirically by taking a first-order Taylor approximation of the equation that determines the relative number of product varieties produced in the two countries, the derivation of which we do not show in the informal discussion in this paper. For information services, the relative number of product varieties is increasing in relative country size, given certain assumptions. Thus, we can replace the relative number of varieties in (1) with a measure of relative country size, $Y_{u} / Y_{k}$. 
The main empirical exercise is to estimate the effect of market size and the effects of trade costs on information services, using the following specification:

$$
\begin{aligned}
\ln \frac{S_{l u k}}{S_{l k k}}= & \beta_{0}+\beta_{1} \ln \frac{Y_{u}}{Y_{k}}+\beta_{2} \ln G D_{u k}+\beta_{3} \ln L D_{u k}+\beta_{4} \ln T_{l u k} \\
& +\beta_{5} \ln \frac{W_{u}}{W_{k}}+\varepsilon_{i u k},
\end{aligned}
$$

where $u$ is the United States, $k$ is the importing country, $Y_{u} / Y_{k}$ is the relative size of countries $u$ and $k, G D_{u k}$ is geographic distance between $u$ and $k, L D_{u k}$ is linguistic distance between $u$ and $k, T_{l u k}$ is $k$ 's ad valorem tariff on imports of product $i$ from country $u, W_{u} / W_{k}$ is relative production costs in countries $u$ and $k$, and $\varepsilon_{i u k}$ is a disturbance term associated with unobserved trade costs between country pair $u k$. Again, by examining relative sales of United States and domestic films, we remove expenditure on motion pictures as a determinant of trade flows in equation (2). In theory, the only role that relative country size plays in determining relative sales is through its impact on the relative size of the motion picture industry in the two countries. A positive coefficient on relative income would indicate that large countries are a relatively attractive site for motion picture production.

In estimating equation (2), we confront several important econometric and measurement issues. These include measuring cultural trade costs and policy trade barriers, allowing for the endogeneity of policy trade barriers, and incorporating the threat of piracy as a source of trade frictions. Each of these is an important issue. In this paper, we will focus on the first problem of measuring trade costs and leave accounting for their endogeneity to future work. The empirical exercise in this paper should be seen as a preliminary exploration of whether trade in information services obeys the laws of gravity.

\subsection{Data and Empirical Application}

In this section, we present data on international trade on motion pictures. We begin by discussing relevant previous research on the motion picture industry, proceed to examine data sources on international trade in motion picture services and on trade costs that may be relevant for motion pictures, and conclude by using data from private industry sources to describe U.S. exports of motion pictures to Europe.

\subsubsection{Previous Literature on Trade in Motion Pictures}

What has previous research discovered about trade in motion pictures? There appears to be tremendous heterogeneity in the performance of movies. De Vany and Walls $(1999,2004)$ and Walls $(2005)$ find that the dis- 
tributions of production cost, box office revenue, and profits (box office revenue minus production cost) have heavy right tails. For example, the mean of production costs is the $62 \mathrm{nd}$ percentile of the distribution, the mean of box office revenues is the 71 st percentile, and 78 percent of movies lose money while 6 percent of movies account for 80 percent of total profits. Perhaps in response to the uncertainty in movie revenues, Goettler and Leslie (2005) find that studios are more likely to cofinance movies that account for a large fraction of their total annual production budget. De Vany and Eckert (1991) and De Vany and Walls (1996) emphasize that the difficulties with forecasting movie demand necessitate the use of short-term, contingent contracts between distributors and exhibitors. Filson, Switzer, and Besocke (2005) argue that these contracts have evolved to help distributors and exhibitors share risks and overcome measurement problems, rather than to resolve information problems.

The attraction of individual films to consumers appears to be shortlived. De Vany and Walls (1999) show that movies earn 66 percent of their box office revenues during their first three weeks of showing. De Vany and Walls (1997) show that a movie has less than a 25 percent chance of lasting seven weeks or more in the top fifty chart and less than a 15 percent chance of lasting ten weeks or more. In a similar vein, Elberse and Eliashberg (2003) find that the U.S. movies with stronger domestic market performance tend to have higher opening week box office revenues when they are released in the foreign markets (where this correlation becomes weaker the longer the time lag between the movies' U.S. releases and foreign releases).

There is increasing interest in the protection of intellectual property in motion pictures, either domestically or internationally. Byers et al. (2004) study successful movie downloads from peer-to-peer file sharing networks. Of the successful downloads, 60 percent appeared on the peer-to-peer networks prior to the movies' DVD release dates. Of the movies that had been released on DVD as of the time of their study, only 5 percent first appeared after their DVD release date on a network. Together, these facts suggest consumer DVD copying is minor compared with insider leaks of DVDs. Turning to trade, McCalman (2004) finds that while Hollywood studios are more likely to use licensing in countries with moderate protection of intellectual property rights (IPR), they tend to use more integrated governance structures in countries with both high and low IPR protection. McCalman (2005) finds that while moderate IPR protection encourages the spread of U.S. movies, either very weak or very strong IPR protections decrease the speed with which U.S. movies are released abroad.

\subsubsection{Data on Trade in Motion Picture Services}

Data on international trade in motion pictures or other information services are very difficult to obtain. The U.S. Bureau of Economic Analysis (BEA) publishes limited bilateral trade flows for the film industry. The 
BEA surveys of U.S. multinational firms provide some industry data on service trade flows (Kozlow and Borga 2004), but only for U.S. parent firms that own subsidiaries located abroad. The BEA Quarterly Survey of Transactions in Selected Services and Intangible Assets with Foreign Persons does give data on foreign receipts from film and television tape rentals, but does not list data on foreign box office revenues earned by U.S. motion pictures.

The U.N.'s Comtrade lists motion picture trade as a commodity, Cinematographic Film Exposed or Developed (SITC 883), which is the reported value of physical shipments of exposed film across borders. The value of physical film shipments appears to vastly understate film revenues. For instance, Comtrade reports 2000 U.S. exposed film exports of $\$ 0.5$ million to France, $\$ 0.5$ million to Germany, and $\$ 6.5$ million to the United Kingdom, while Screendigest.com reports 2000 box office revenues for U.S. films of $\$ 513$ million in France, $\$ 615$ million in Germany, and $\$ 429$ million in the United Kingdom (Hancock and Jones 2003).

We evaluate the demand for U.S. films, other foreign films, and domestically made films using data on box office revenues by country and year. Box office revenues are equivalent to the c.i.f. (customs, insurance, freight) value of motion picture services consumed in cinemas, plus retail markups. These revenues include import duties, transport costs, and other trade costs incurred in delivering the service to the consumer, as well as sales taxes and exhibition fees collected by cinemas. Box office revenues are consistent with the trade-cost-inclusive measure of sales in equation (1). Individuals may consume motion picture services through cinemas (for new movie releases) or through video rentals, video purchases, or pay TV (for previous movie releases). ${ }^{2}$ Distributors tend to release movies to cinemas first and to retail outlets and pay TV operators later in time, suggesting for a given film these services do not compete contemporaneously. Recently, studios have experimented with releasing films in the U.S. market in cinemas and in video format simultaneously, but this practice appears to be rare in foreign markets. As of yet, the provision of motion picture services through the Internet accounts for a very small share of global film revenues. In this paper, we limit our analysis to motion picture revenues earned through cinema exhibition (box office revenues).

Data on box office revenues for the period 1995 to 2004 are available from Screendigest.com. For this paper, we use data on cinema exhibition and distribution in nineteen European countries from Hancock and Jones (2003). In each country and year, Screendigest.com reports the number of films screened, total film attendance, and total box office revenues for films

2. Data on DVD/video sales and rentals are very difficult to get. For example, Screendigest .com charges $£ 5,000$ for access to its Video and DVD Global Intelligence database. We are still in the process of acquiring such data. 
imported from the United States, films imported from other major producing countries, and films produced domestically. The company also reports attendance and revenue for each of the ten top-grossing films by country and year and other national market data. Screendigest.com compiles these data from government agencies, national film bodies, film exhibitor and distributor associations, and company spokespeople.

An important issue in using data on box office revenues is how to classify the nationality of a motion picture. Screendigest.com defines the origin country for a film by the location of the company that produces the film. Production companies (e.g., 20th Century Fox in the United States) oversee the writing or purchase of screenplays and musical scores, casting, costume and set design, animation, filming, sound recording, and editing, marketing, distribution, and financing. ${ }^{3}$

To consider how data on trade in motion pictures from Comtrade and Screendigest.com compare, figure 6.1, panel A plots the value of total film imports reported by Comtrade and box office revenues for foreign films reported by Screendigest.com for nineteen European countries for the period 1992 to 2002; figure 6.1, panel B shows a similar plot for film imports from the United States and box office revenues for U.S. films in Europe. For either total imports or imports from the United States, box office revenues greatly exceed film imports reported by Comtrade. The magnitude of the differences are perhaps more apparent in table 6.1, which shows the Comtrade value of film imports and the Screendigest.com value of box office revenues for foreign films, by year, for Europe. Over the sample period, the average ratio of the former to the latter is 46.2. Table 6.2 shows averages over 1992 to 2002 by country for Comtrade film imports and Screendigest.com foreign film box office revenues. There appears to be little systematic relationship between the two series. Over the sample period, the average ratio of box office revenues to film imports varies from a low of 20.7 in Austria to a high of 155.8 in Italy. It appears that Comtrade data on film imports (at least for Europe) give no meaningful indication of foreign sales of motion picture services.

\subsubsection{U.S. Exports of Motion Pictures}

The data we use for our analysis is from Hancock and Jones (2003), which gives information on U.S. exports of motion pictures to Europe. While the United States is by far and away the dominant player in the European film industry, there is substantial variation across countries in the share of the market held by U.S. studios. It is this variation that we exploit in the gravity estimation in the following section.

Figure 6.2 shows total box office revenues and average ticket prices in the

3. Independent exhibition companies tend to oversee the screening of movies to consumers in destination markets. 
A

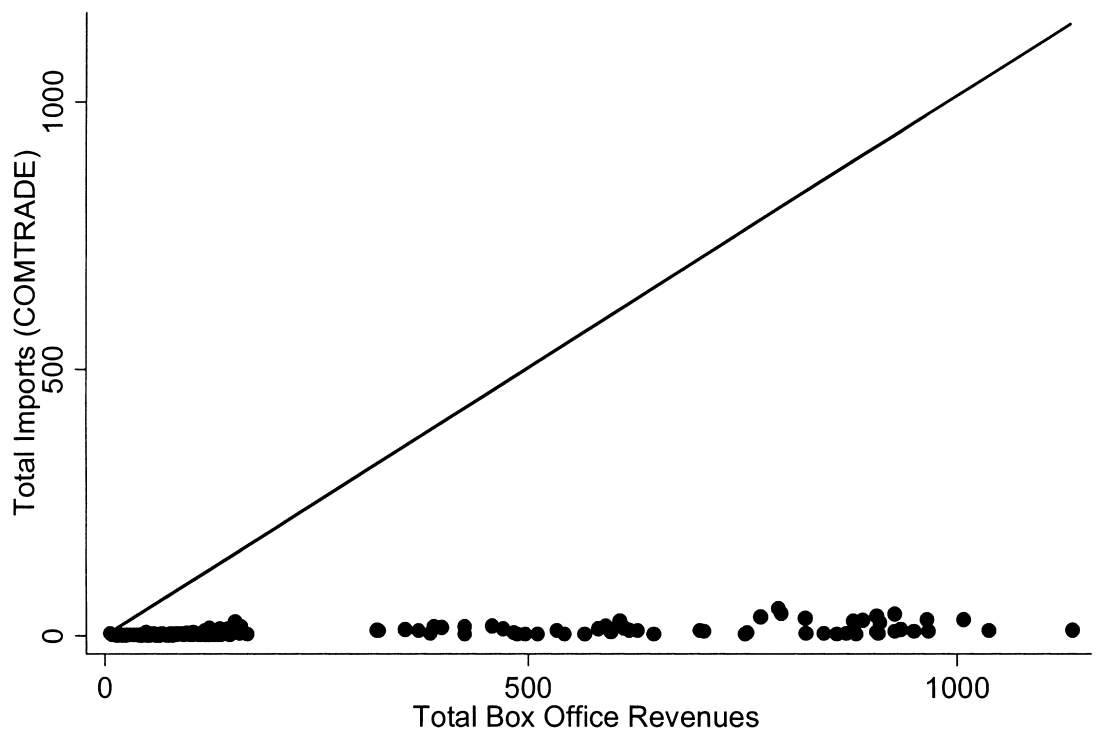

B

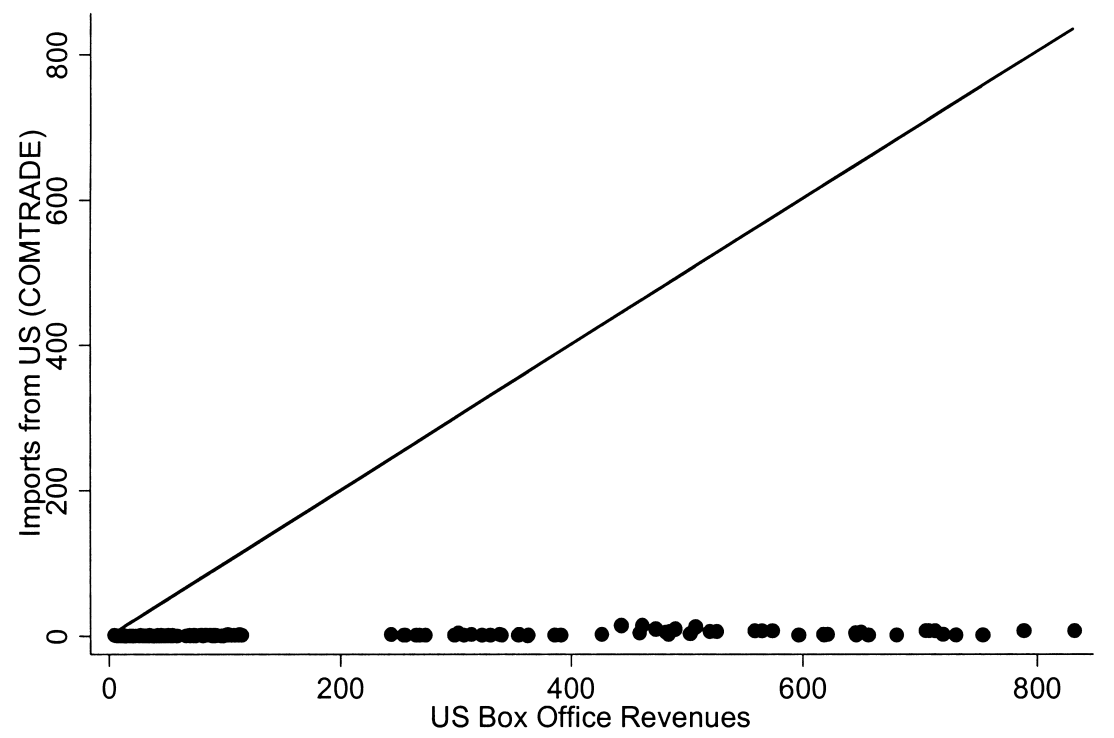

Fig. 6.1 Film imports from comtrade versus box office revenues of foreign films in Europe: $A$, total imports and total box office revenues; $B$, imports from the United States and U.S. box office revenues 


\begin{tabular}{ccc}
\hline Year & $\begin{array}{c}\text { Total film imports } \\
\text { (Comtrade) }\end{array}$ & $\begin{array}{c}\text { Total box office revenues } \\
\text { for foreign films } \\
\text { (Screendigest.com) }\end{array}$ \\
\hline 1992 & 140.9 & $3,756.2$ \\
1993 & 99.9 & $3,520.3$ \\
1994 & 96.0 & $3,902.5$ \\
1995 & 103.1 & $4,226.9$ \\
1996 & 109.8 & $4,502.5$ \\
1997 & 92.5 & $4,612.5$ \\
1998 & 90.5 & $5,062.5$ \\
1999 & 93.3 & $4,891.5$ \\
2000 & 91.2 & $4,409.3$ \\
2001 & 78.0 & $4,868.7$ \\
2002 & 95.8 & $5,245.2$ \\
\hline
\end{tabular}

Notes: Column 2 reports total imports of SITC 8830 from Comtrade for nineteen countries in Europe; Column 3 reports total box office revenues for foreign films in these countries (as reported by Hancock and Jones 2003). The nineteen countries are Austria, Belgium, Czech Republic, Denmark, Finland, France, Germany, Greece, Hungary, Ireland, Italy, Netherlands, Norway, Poland, Portugal, Spain Sweden, Switzerland, and the United Kingdom.

Table 6.2

Imports of motion pictures by country (in millions of U.S. dollars)

\begin{tabular}{lcc}
\hline Country & $\begin{array}{c}\text { Mean film imports } \\
\text { (Comtrade) }\end{array}$ & $\begin{array}{c}\text { Mean box office revenues } \\
\text { for foreign films } \\
\text { (Screendigest.com) }\end{array}$ \\
\hline Austria & 4.1 & 85.5 \\
Belgium & 2.4 & 110.8 \\
Czech Republic & 0.6 & 15.5 \\
Denmark & 1.0 & 70.8 \\
Finland & 1.2 & 42.2 \\
France & 34.1 & 880.3 \\
Germany & 6.4 & 812.3 \\
Greece & 1.3 & 50.3 \\
Hungary & 1.0 & 23.5 \\
Ireland & 0.4 & 51.7 \\
Italy & 3.3 & 518.9 \\
Netherlands & 1.5 & 118.5 \\
Norway & 2.4 & 70.9 \\
Poland & 1.8 & 51.9 \\
Portugal & 1.9 & 49.5 \\
Spain & 13.9 & 425.7 \\
Sweden & 1.9 & 119.8 \\
Switzerland & 11.9 & 141.7 \\
United Kingdom & 9.7 & 822.9
\end{tabular}

Notes: Column 2 reports the average value of imports for SITC 8830 from Comtrade across the years 1992-2002; Column 3 reports average box office revenue for foreign films from Screendigest.com across the years 1992-2002. 


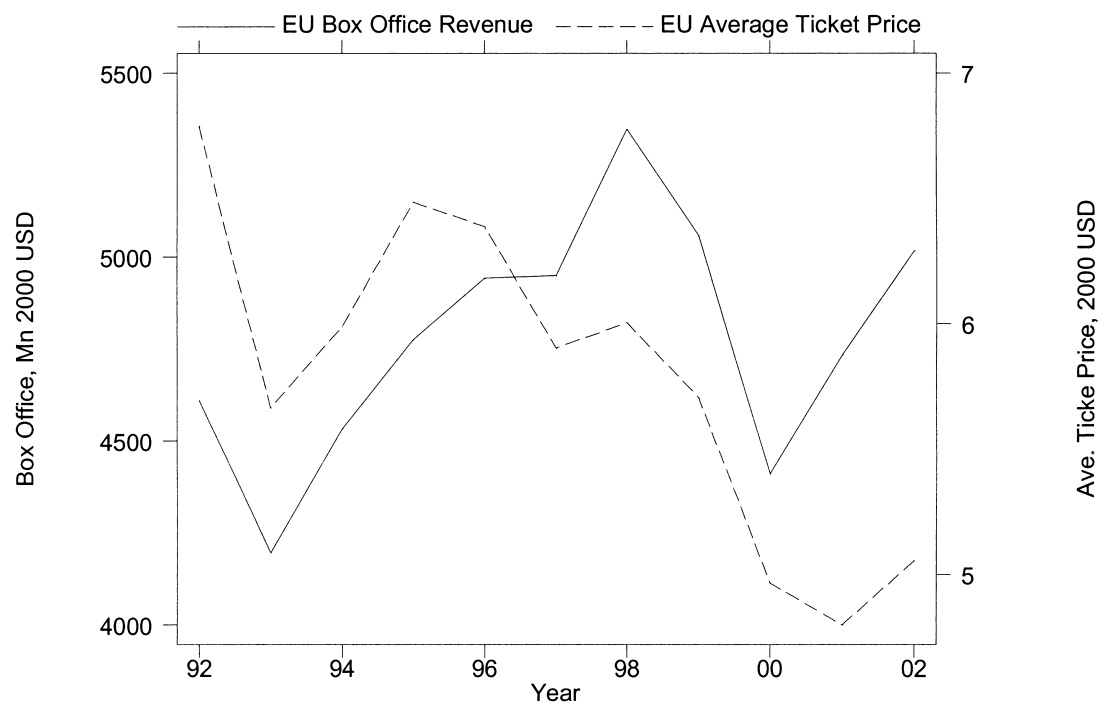

Fig. 6.2 Box office revenues in Europe

nineteen European countries. Revenues grow modestly over the sample period, showing considerable volatility. The surge in revenues in 1998 is associated with the movie, Titanic, which at the time was the highest-grossing movie in history. Ticket prices fall over the sample period, due in part to a rising share in European film revenues of lower-priced markets in central and eastern Europe. The importance of high-grossing films is further evident in figure 6.3, which shows the share of the top ten films in total box office revenues. The top ten share fluctuates considerably, reaching its height in 1998 with Titanic, with an average of the period of 0.48 .

For Europe as a whole, the United States is the most important source of motion pictures. Figure 6.4 shows the share of box office revenues of U.S. films, domestically made films, and other foreign films. Over the sample period, the U.S. revenue share averages 0.69 and is quite stable. Revenue shares for domestic films and films from third countries are roughly equal. The dominance of U.S. studios is due largely to a relatively small number of high-grossing films. This is seen in figure 6.5, which shows the average number of films released in Europe by origin country or region. While the U.S. share of box office revenues is over twice that for domestic and nonU.S. foreign films combined, the number of U.S. film releases is slightly smaller than the sum of domestic and non-U.S. foreign releases. Domestic and non-U.S. foreign releases tend to have small gross revenues.

Countries in Europe vary in the size of their domestic motion picture industries. Figure 6.6 shows the ratio of local box office revenues for U.S. films to local box office revenues for domestically produced films by Euro- 


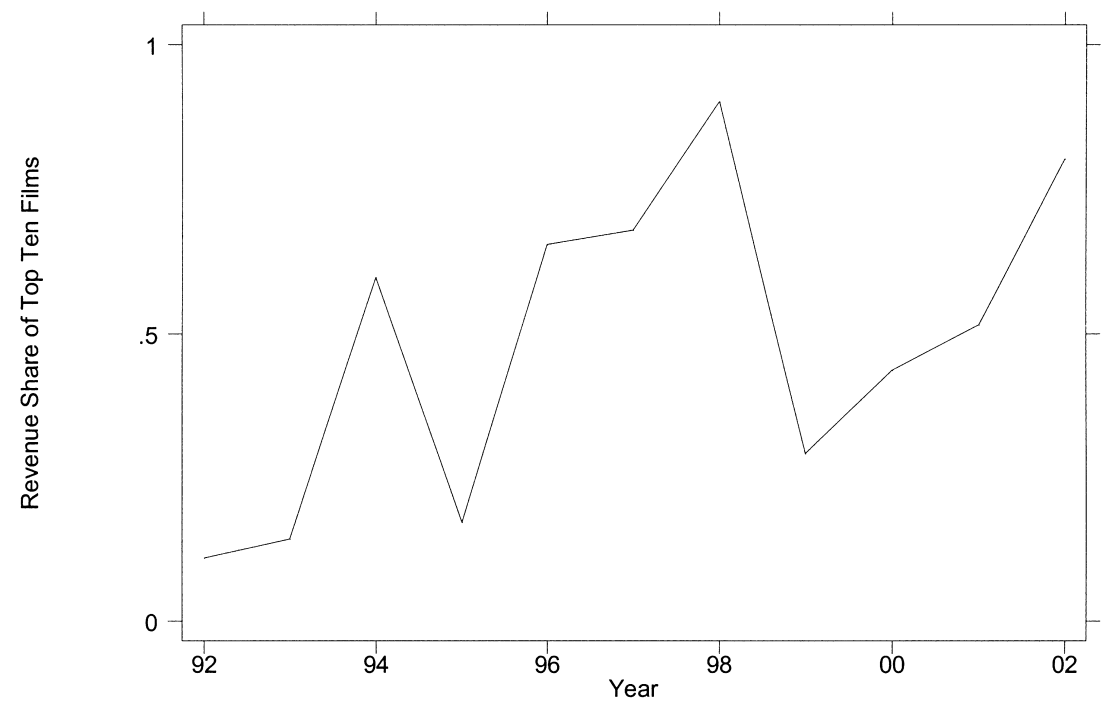

Fig. 6.3 Share of high-grossing films in European box office revenues

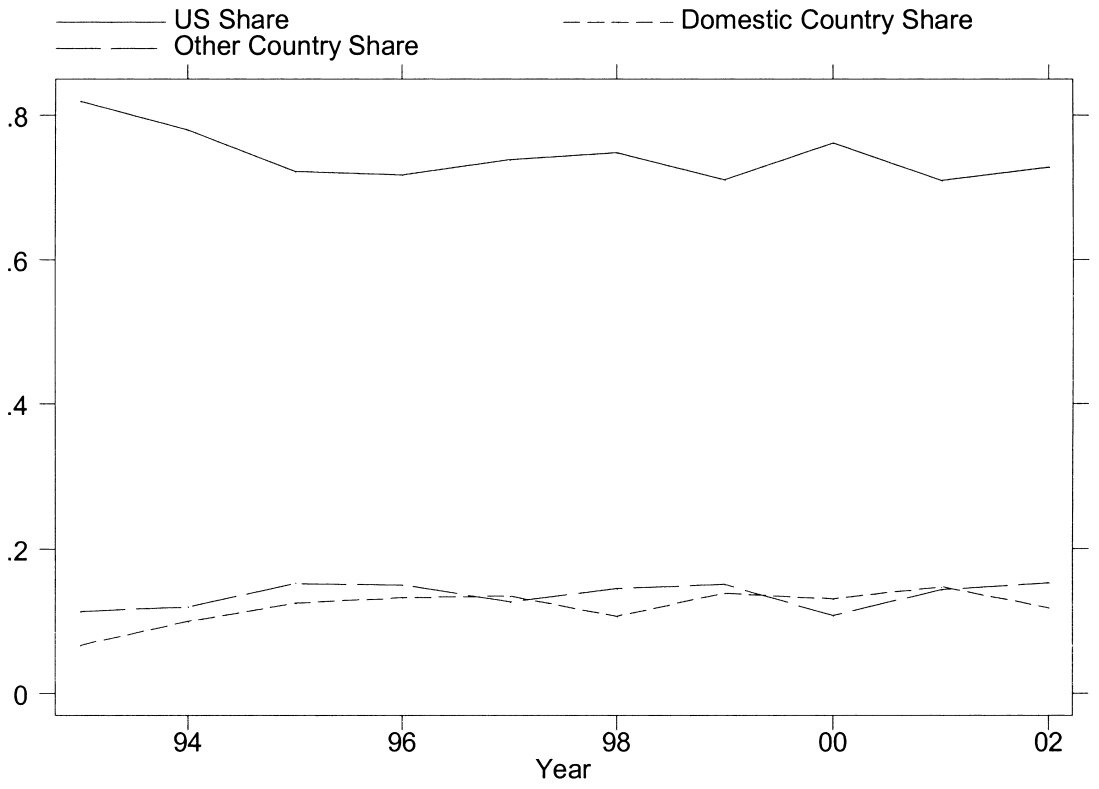

Fig. 6.4 U.S. share of box office revenues in Europe 


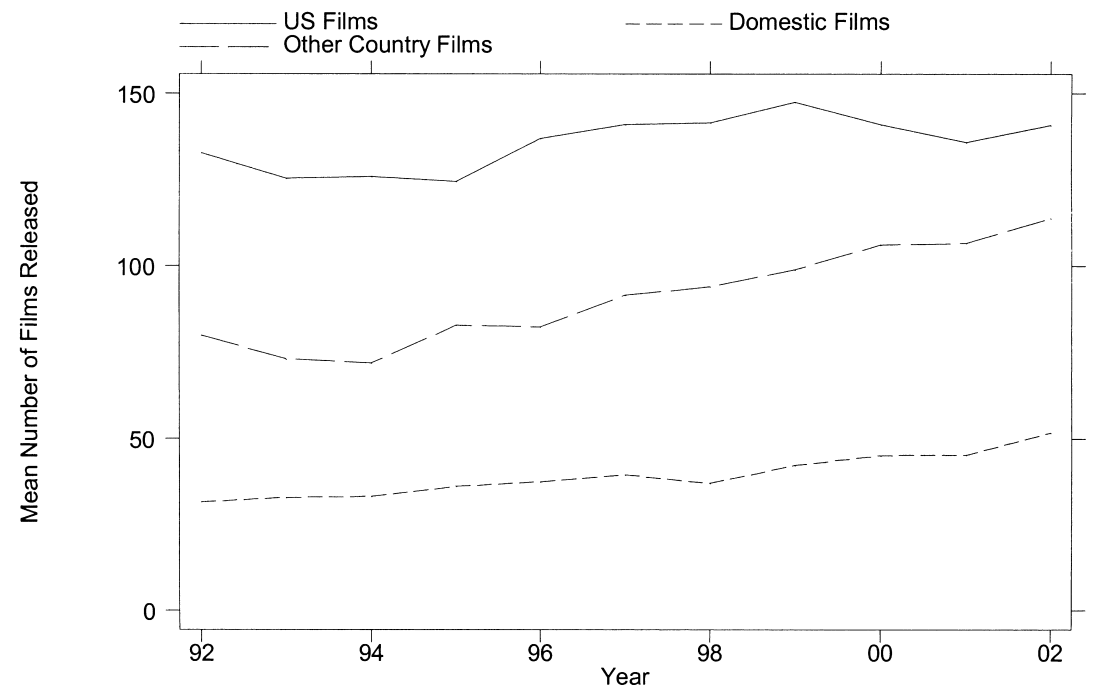

Fig. 6.5 Number of films released in Europe

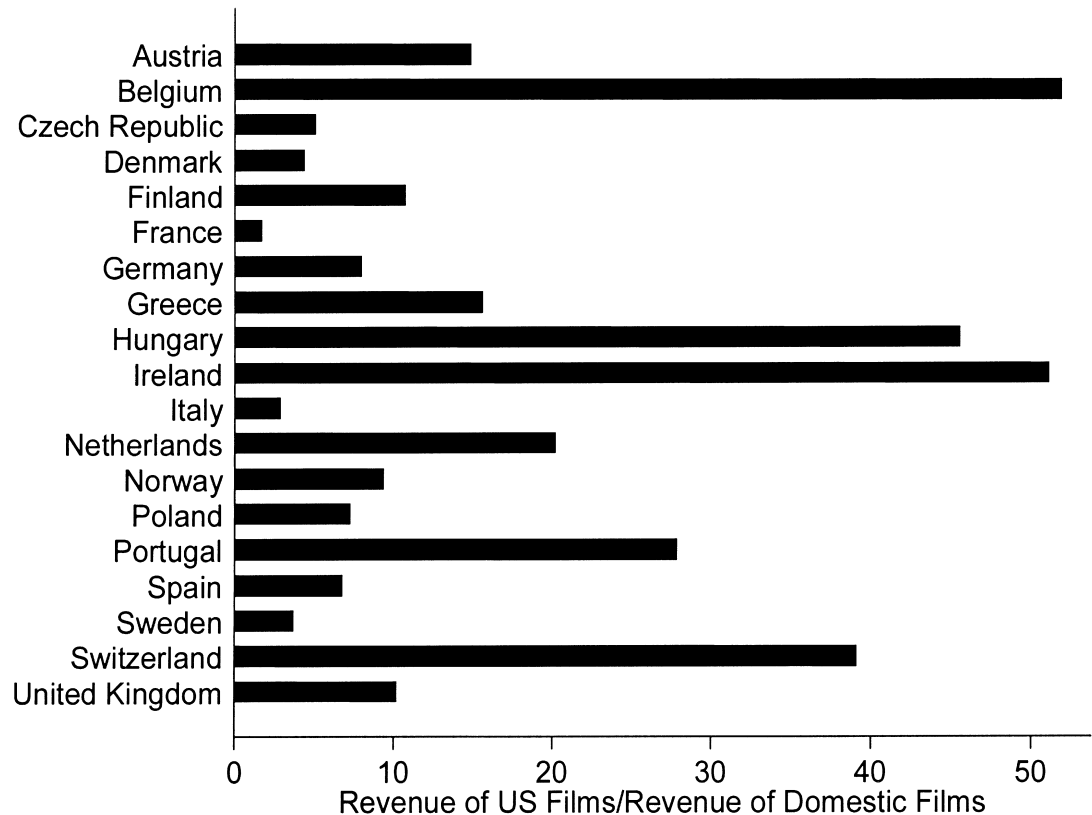

Fig. 6.6 Revenues of U.S. and domestic films in Europe, 1995 to 2002 
pean country averaged over 1995 to 2002, which is the period for which data on every country is available. The log of this ratio is the dependent variable in equation (2). Relative U.S. film revenues range from over fifty times domestic film revenues in Belgium and Ireland to less than five times in France. Differences in the size of national movie industries in part reflect differences in country size. Relative U.S. film revenues are strongly positively correlated with the ratio of U.S. GDP to national GDP, with the log correlation between relative film revenues and relative GDP a highly significant 0.45 . Differences in trade costs vis-à-vis the United States may also affect the size of national movie industries. As we discuss next, countries in Europe vary both in their cultural proximity to the United States and in the protection they afford their domestic motion picture industries.

\subsubsection{Trade Costs in Motion Pictures}

Before turning to the estimation, we need to identify data on trade costs relevant to motion pictures. We measure cultural trade costs between the United States and its trading partners using indicators of the linguistic distance between English and other countries' primary languages. ${ }^{4}$ Distances between languages capture the extent to which two countries share a common linguistic heritage, which may indicate how easily cultural ideas flow between them. Linguists group languages according to family trees. English belongs to the Indo-European language family, whose speech varieties have been examined extensively. In a classic study, Dyen, Kruskal, and Black (1992) measure the similarity between ninety-five Indo-European speech varieties. They create a percentage cognate matrix, which identifies for each pair of languages the fraction of words for 200 basic meanings (e.g., all, and, father, ice) that can be traced back to a common ancestral word. In Europe, the Dyen index for English ranges from a high of 0.60 for Dutch (indicating that 60 percent of English and Dutch words for the 200 basic meanings share a common ancestral word) to 0.23 for Czech. ${ }^{5}$

As an additional indicator of linguistic distance, we use the relative ease with which U.S. citizens learn foreign languages. After receiving a foreign job posting, employees of the U.S. Department of State (DOS) undergo twenty-four weeks of foreign language training, at the end of which they are tested on their proficiency. Chiswick and Miller (2004) use the average scores of DOS test takers by language in the early 1990s as a metric of the distance between English and forty-three other languages. The DOS index encapsulates both linguistic differences between English and other lan-

4. Two countries in our sample, Belgium and Switzerland, do not have a single dominant language. For these countries, we calculate linguistic distance as the weighted average of the distance between English and their primary languages, using data in Melitz (2002) and Gordon (2005) to calculate language weights.

5. For other work on trade using the Dyen index, see Ginsburgh, Ortuno-Ortin, and Weber (2005). 
guages and the exposure of U.S. citizens to other cultures. United States citizens have an easier time learning Spanish (average score of 2.25) than Japanese (average score of 1) in part because Spanish is more similar to English and in part because U.S. citizens have been more exposed to Spanish. ${ }^{6}$ A disadvantage of the DOS measure is that language tests are not randomly assigned. Department of State employees may be posted to particular countries based in part on their perceived ability to learn a language. Thus, test takers may be selected into a specific exam based on their unobserved ability, which could compress variation in DOS exam scores. The correlation between the Dyen and DOS indices is 0.65.

To measure policy barriers on motion-picture trade, we use a countrylevel trade barrier index (TBI) constructed by Marvasti and Canterberry (2005) for thirty-three countries in the early 1990s. Their index is the average across six dummy variables for trade barriers in motion pictures. These dummies capture the presence of tariffs on film imports, quantitative restrictions on film imports, levies on imported video sales, subsidies to domestic film producers, overall trade barriers on service imports, and obstacles in enforcing property rights. In Europe, France and Italy have the most restrictive barriers on motion pictures, followed closely by Spain. The Netherlands, Norway and Sweden have the least restrictive barriers. Belgium, Germany, Switzerland, and the United Kingdom have intermediate levels of trade barriers. Marvasti and Canterberry (2005) find that their trade barrier index is positively correlated with imports of U.S. motion pictures. However, they use a gravity specification that does not control for multilateral resistance, contrary to the estimation strategy suggested by Anderson and van Wincoop (2004). Using a theoretically grounded gravity specification, as in equation (2), we find a negative correlation between trade levels and trade costs in motion pictures.

\subsection{Gravity Estimation Results}

Table 6.3 reports estimates of equation (2). The dependent variable is the $\log$ ratio of box office revenues of U.S. films to box office revenues of domestic films, by country. The independent variables are the log ratio of U.S. to domestic GDP; the log ratio of U.S. to domestic average annual earnings for skilled labor in manufacturing (from the UNIDO Industrial Database); log geographic distance to the United States; the log trade barrier index from Marvasti and Canterbury (2005) and a dummy variable for whether the country has no TBI data; the log Dyen index and a dummy variable for whether a country's primary language is non-Indo-European (for which the Dyen index is undefined); and the log Department of State language exam index from Chiswick and Miller (2004) and a dummy variable for

6. The highest average score is 3, for both Afrikaans and Swedish. 
Table 6.3

Gravity model estimation results for U.S. exports of motion picture services

\begin{tabular}{|c|c|c|c|c|c|c|}
\hline & (1) & (2) & (3) & (4) & (5) & (6) \\
\hline $\ln Y_{u s} / Y_{k}$ & $\begin{array}{c}0.450 \\
(0.073)\end{array}$ & $\begin{array}{c}0.552 \\
(0.114)\end{array}$ & $\begin{array}{c}0.456 \\
(0.092)\end{array}$ & $\begin{array}{c}0.483 \\
(0.072)\end{array}$ & $\begin{array}{c}0.790 \\
(0.132)\end{array}$ & $\begin{array}{c}0.812 \\
(0.110)\end{array}$ \\
\hline $\ln W_{u s} / W_{k}$ & $\begin{array}{l}-0.324 \\
(0.128)\end{array}$ & $\begin{array}{c}-0.175 \\
(0.133)\end{array}$ & $\begin{array}{l}-0.23 \\
(0.139)\end{array}$ & $\begin{array}{c}-0.480 \\
(0.157)\end{array}$ & $\begin{array}{l}-0.007 \\
(0.140)\end{array}$ & $\begin{array}{c}-0.452 \\
(0.144)\end{array}$ \\
\hline ln Distance & $\begin{array}{l}-1.526 \\
(0.893)\end{array}$ & $\begin{array}{c}-0.523 \\
(1.161)\end{array}$ & $\begin{array}{c}-0.412 \\
(1.037)\end{array}$ & $\begin{array}{c}-2.077 \\
(0.988)\end{array}$ & $\begin{array}{c}1.202 \\
(1.448)\end{array}$ & $\begin{array}{c}-2.119 \\
(1.207)\end{array}$ \\
\hline $\ln$ TBI & & $\begin{array}{c}-0.268 \\
(0.360)\end{array}$ & & & $\begin{array}{c}0.774 \\
(0.435)\end{array}$ & $\begin{array}{c}-0.878 \\
(0.289)\end{array}$ \\
\hline No TBI & & $\begin{array}{l}-1.123 \\
(0.7020)\end{array}$ & & & $\begin{array}{c}0.336 \\
(0.7700)\end{array}$ & $\begin{array}{l}-3.458 \\
(0.6860)\end{array}$ \\
\hline ln Dyen & & & $\begin{array}{c}-0.493 \\
(0.162)\end{array}$ & & $\begin{array}{c}-0.882 \\
(0.234)\end{array}$ & \\
\hline Non-Indo-European & & & $\begin{array}{c}-0.634 \\
(0.256)\end{array}$ & & $\begin{array}{c}-1.106 \\
(0.281)\end{array}$ & \\
\hline $\ln$ DOS & & & & $\begin{array}{c}-1.309 \\
(0.662)\end{array}$ & & $\begin{array}{c}-5.534 \\
(0.880)\end{array}$ \\
\hline English & & & & $\begin{array}{c}-0.799 \\
(0.691)\end{array}$ & & $\begin{array}{c}-4.515 \\
(0.829)\end{array}$ \\
\hline$R^{2}$ & 0.235 & 0.271 & 0.271 & 0.261 & 0.337 & 0.423 \\
\hline $\mathrm{N}$ & 171 & 171 & 171 & 171 & 171 & 171 \\
\hline
\end{tabular}

Notes: The dependent variable is the log ratio of box office revenues of U.S. films to box office revenues of domestic films. The independent variables are the log ratio of U.S. to domestic GDP $\left(\ln Y_{u s} / Y_{k}\right)$; the log ratio of U.S. to domestic average annual earnings for skilled labor in manufacturing $\left(\ln W_{u s} / W_{k}\right)$; log geographic distance to the United States (ln Distance); the log trade barrier index from Marvasti and Canterbury (2005) and a dummy variable for whether the country has no TBI data (ln TBI, No TBI); the log Dyen index and a dummy variable for whether a country's primary language is non-Indo-European (ln Dyen, Non Indo-Euro); the log Department of State language exam index from Chiswick and Miller (2004) and a dummy variable for whether a country's primary language is English (ln DOS, English). The specification also includes year dummies, which are unreported. The sample is the nineteen European countries (see table 6.1) over the period 1992 to 2002.

whether a country's primary language is English (for which the DOS index is undefined). The specification also includes year dummies, which are unreported. The sample is the nineteen European countries included in Hancock and Jones (2003) over the period 1992 to 2002. Since there are only nineteen countries and the six trade-cost variables do not vary across time, it is not feasible to include all trade cost measures in the same regression. For some trade cost measures, the results are sensitive to which other trade costs are included as regressors.

Relative U.S. film revenues are increasing in relative U.S. GDP. ${ }^{7}$ The

7. The coefficients on GDP are not directly comparable to standard gravity model estimates (which are closer to 1), since our dependent variable is not log trade but log trade relative to log domestic consumption. 
United States has a more dominant position in the motion picture industries of smaller countries. These results suggest that larger countries have an advantage as a production location in motion pictures, consistent with results on market-size effects in the theoretical models in Krugman (1980) and Helpman and Krugman (1985) and gravity results for differentiated manufacturing industries in Feenstra, Markusen, and Rose (1998) and Hanson and Xiang (2004). Given fixed costs in producing motion pictures and trade costs (associated with language, culture, and trade policy) in delivering motion picture services, studios appear to have an incentive to situate production in large countries. As a result, the dominance of U.S. studios is weakest in the larger European markets, including France, Germany, Italy, Spain, and the United Kingdom, which is apparent in figure 6.6.

Exports of U.S. films are smaller in countries where U.S. wages are relatively high. This is consistent with higher production costs deterring U.S. exports. Trade costs appear to affect the ability of U.S. studios to penetrate foreign markets. Relative U.S. film revenues are decreasing in each of the trade cost measures.

The estimated coefficient on the trade barrier index is negative in two specifications, as expected, but precisely estimated in only one case. There is an obvious concern about the endogeneity of policy trade barriers. Countries whose unobserved characteristics are associated with weaker domestic film industries may be more likely to impose import protection for motion pictures, which would tend to introduce positive bias in the coefficient estimate on the trade barrier index. A further problem is that we do not observe trade barriers for all countries in the sample. Controlling for the endogeneity of trade barriers and expanding the coverage of this measure to include additional countries are important tasks for further research.

The coefficient on the Dyen index, which is the most precisely estimated trade-cost parameter, indicates that, all else equal, moving from an English-speaking country (Dyen index of 1) to a Czeck-speaking country (Dyen index of 0.23) would reduce U.S. film revenues relative to domestic film revenues by $72 \log$ points, based on results in column (3), which is a large effect. Relative U.S. film revenues are also substantially lower in nonIndo-European-language countries, which in our sample include Finland, Hungary, and Norway. Languages that belong to the same family share common ancestral origins in their speech varieties. Countries whose languages belong to different language families may have relatively few historical links between their cultures, which could tend to dampen trade in cultural goods such as motion pictures.

The coefficient on the DOS language index is negative, again indicating that trade is lower between countries that are more linguistically distant from the United States, but is quite sensitive to which other regressors are included in the estimation. 


\subsection{Summary}

In this project, we develop a theoretical framework to examine international trade in information services and apply this framework to an empirical study of trade in motion pictures. Despite the growing importance of services, in general, and information services, in particular, for U.S. trade, the export performance of these sectors has been the subject of little empirical research.

The intellectual merit of our research comes from identifying the extent to which the size of the U.S. market has contributed to the global concentration of the motion picture industry in the U.S. and using newly available measures of linguistic distance to estimate the impact of cultural trade barriers on trade in motion pictures. Market size, language, and trade are each important determinants of U.S. motion picture exports.

To date, the poor quality of published data on trade in services has hampered research on the sector's role in the global economy. However, poor data quality does not mean the U.S. current account is mismeasured. Foreign revenues earned by U.S. motion pictures still appear in the current account, either as exports or as investment income (resulting from license agreements, royalties, or foreign sales by affiliates of U.S. multinationals).

\section{References}

Amiti, M., and S.-J. Wei. 2005. Fear of service outsourcing: Is it justified? Economic Policy 20:308-47.

Anderson, J. E., and E. van Wincoop. 2004. Trade costs. Journal of Economic Literature 42 (3):691-751.

Baldwin, R. E., R. E. Lipsey, and D. Richardson. 1998. Geography and ownership as bases for economic accounting. Chicago: University of Chicago Press.

Berndt, E., and C. R. Hulten. 2007. Hard-to-measure goods and services: Essays in honor of Zvi Griliches. Chicago: University of Chicago Press.

Byers, S., L. F. Cranor, E. Cronin, D. Korman, and P. McDaniel. 2004. An analysis of security vulnerabilities in the movie production and distribution process. Telecommunications Policy. Special Issue, 28 (7-8):619-44.

Chiswick, B., and P. Miller. 2004. Linguistic distance: A quantitative measure of distance between English and other Languages. IZA Discussion Paper no. 1246.

Council of Economic Advisors. 2004. Economic Report of the President. Washington, D.C.: GPO.

Davis, D. R., and D. E. Weinstein. 1999. Economic geography and regional production structure. European Economic Review 43:379-407.

2002. The factor content of trade. In Handbook of international trade, ed. E. K. Choi and J. Harrigan, 119-46. London: Blackwell. 2003. Market access, economic geography and comparative advantage: An empirical assessment. Journal of International Economics 59 (1):1-24.

De Vany, A. S., and R. D. Eckert. 1991. Motion pictures antitrust: The paramount cases revisited. Research in Law and Economics 14:51-112. 
De Vany, A. S., and W. D. Walls. 1996. Bose-Einstein dynamics and adaptive contracting in the motion pictures industry. Economic Journal 1493-1514.

1997. The market for motion pictures: Rank, revenue, and survival. Economic Inquiry 35 (4):783-97.

1999. Uncertainty in the movie industry. Journal of Cultural Economics 23 (4):285-318.

. 2004. Motion picture profit, the stable Paretian hypothesis, and the curse of the superstar. Journal of Economic Dynamics and Control 28 (6):1035-57.

Dyen, I., J. B. Kruskal, and P. Black. 1992. An Indoeuropean classification: A lexicostatistical experiment. Transactions of the American Philosophical Society 82 (5):1-132.

Elberse, A., and J. Eliashberg. 2003. Demand and supply dynamics for sequentially released products in international markets: The case of motion pictures. Marketing Science 22 (3):329-54.

Feenstra, R. C. 2004. Advanced international trade: Theory and evidence. Princeton, NJ: Princeton University Press.

Feenstra, R. C., and G. H. Hanson. 2002. Global production and inequality: A survey of trade and wages. In Handbook of international trade, ed. E. K. Choi and J. Harrigan, 146-85. London: Blackwell.

Feenstra, R. C., J. R. Markusen, and A. Rose. 1998. Understanding the home market effect and the gravity equation: The role of differentiating goods. NBER Working Paper no. 6804. Cambridge, MA: National Bureau of Economic Research.

Filson, D., D. Switzer, and P. Besocke. 2005. At the movies: The economics of exhibition contracts. Economic Inquiry 43 (2):354-69.

Freund, C., and D. Weinhold. 2002. The Internet and international trade in services. American Economic Review 92 (2):236-40.

Ginsburgh, V., I. Ortuno-Ortin, and S. Weber. 2005. Disenfranchisement in linguistically diverse societies: The case of the European Union. Journal of the European Economic Association 3 (4):946-65.

Goettler, R. L., and P. Leslie. 2005. Cofinancing to manage risk in the motion picture industry. Journal of Economics and Management Strategy 14 (2):231-61.

Gordon, R. G., Jr., ed. 2005. Ethnologue: Languages of the world, 15th ed. Dallas, TX: SIL International.

Griliches, Z. 1992. Output measurement in the service sectors. Chicago: University of Chicago Press.

Hancock, D., and C. Jones. 2003. Cinema distribution and exhibition in Europe, 2nd ed. London: Screendigest.

Hanson, G. H., and C. Xiang. 2004. The home market effect and bilateral trade patterns. American Economic Review 94:1108-29.

Head, K., and J. Ries. 2001. Increasing returns versus national product differentiation as an explanation for the pattern of US-Canada trade. American Economic Review 91 (4):858-76.

Helpman, E., and P. Krugman. 1985. Market structure and foreign trade. Cambridge, MA: The MIT Press.

Holmes, T. J., and J. J. Stevens. 2002. The home market and the pattern of trade: Round three. Federal Reserve Bank of Minneapolis Staff Report no. 304.

Hooper, P., and D. Richardson. 1991. International economic transactions: Issues in measurement and empirical research. Chicago: University of Chicago Press.

Hoskins, C., S. McFadyen, and A. Finn. 1997. Global television and film. Oxford: Clarendon.

Janeba, E. 2004. International trade and cultural identity. NBER Working Paper no. 10426. Cambridge, MA: National Bureau of Economic Research. 
Johnson, N. L., S. Kotz, and N. Balakrishnan. 1994. Continuous univariate distributions. New York: Wiley.

Kozlow, R., and M. Borga. 2004. Offshoring and the U.S. balance of payments. U.S. Bureau of Economic Analysis Working Paper 2004-05.

Krugman, P. 1980. Scale economies, product differentiation, and the pattern of trade. American Economic Review 70:950-59.

Marvasti, A., and E. R. Canterberry. 2005. Cultural and other barriers to motion pictures trade. Economic Inquiry 43 (1):39-54.

McCalman, P. 2004. Foreign direct investment and intellectual property rights: Evidence from Hollywood's global distribution of movies and videos. Journal of International Economics 62 (1):107-23.

-2005. International diffusion and intellectual property rights: An empirical analysis. Journal of International Economics 67:353-72.

Melitz, M. J. 2002. Language and foreign trade. CEPR Discussion Paper no. 3590.

. 2003. The impact of trade on intra-industry reallocations and aggregate industry productivity. Econometrica 71 (6):1695-1725.

Rauch, J. E., and V. Trindade. 2006. Neckties in the tropics: A model of international trade and cultural diversity. University of Missouri Working Paper no. 0517.

Siwek, S. E. 2004. Copyright industries in the U.S. economy: The 2004 report. Economists Incorporated for the International Intellectual Property Alliance. Washington, D.C.: IIPA.

- 2005. Engines of growth: Economic contributions of U.S. intellectual property industries. Economists Incorporated for NBC Universal. Washington, D.C.: IIPA.

Tybout, J. R. 2002. Plant and firm-level evidence on 'new' trade theories. In Handbook of international trade, ed. E. K. Choi and J. Harrigan, 388-415. London: Blackwell.

Walls, W. D. 2005. Demand stochastics, supply adaptation, and the distribution of film earnings. Applied Economics Letters 12 (10):619-23.

\section{Comment Phillip McCalman}

International trade studies the exchange of goods and services between countries. However, for the most part, empirical research has focused on the former-goods, and neglected the latter-services. While the historical reasons for this concentration are relatively clear-goods are generally thought of as traded, while services (haircuts, physician consultation) are naturally thought of as nontraded - the pronounced shift in the structure of most economies toward services, along with technological change, has dramatically changed this notion. Consequently, in contemporary discussions of globalization, reference is not only made to the integration of goods markets but also increasingly to the integration of services markets, with service outsourcing receiving particular attention. With this change

Phillip McCalman is an associate professor of economics at the University of California, Santa Cruz. 